\title{
Motives, Perceptions and Processes of Madurese Migrant Workers
}

\author{
Iriani Ismail ${ }^{1}$, Netty Dyah Kurniasari ${ }^{2}$, Eni Sri Rahayu ${ }^{3}$, \\ \{nettyutm@gmail.com ${ }^{2}$ \} \\ Department of Management, Trunojoyo University of Madura ${ }^{1}$, \\ Department of Communication, Trunojoyo University of Madura ${ }^{2}$, \\ Department of Development Economy, Trunojoyo University of Madura ${ }^{3}$
}

\begin{abstract}
The condition of Indonesia's labor problems in East Java is very high. Based on the data there are about seven thousand problematic Indonesian Workers in East Java. Of these, the migrant worker from Madura is around 70\%. They come from 4 regencies, namely Bangkalan, Sampang, Pamekasan and Sumenep. Based on these facts, this article wants to analyze the motives and their processes to become migrant workers. Specifically, the purpose of this research is to explore the motives behind the Madurese to become migrant workers. This study also wants to analyze the process of becoming migrant worker. Furthermore, this research wants to know what skills are prepared and needed by migrant workers before going abroad. This informant is a migrant worker from Pamekasan Regency. Data collection methods are interviews and observations. The results show that the motives of being migrant workers are varied, namely economic reasons, education and prestige. The process is diverse, some use brokers (illegal) and some do not use brokers (illegal).
\end{abstract}

Keywords: Motive, Migrant Workers, Madura.

\section{Introduction}

Four districts in Madura, according to the records of Disnakertransduk East Java, entered the five regions with the highest rate of troubled migrant workers in East Java [1]. Throughout 2014, there were 7,493 Indonesian migrant workers (BMI) from East Java who were in trouble, ranging from minor to severe violations. "Of that amount, around $70 \%$ percent are from Madura. The problematic TKIs include Sampang, Pamekasan and Sumenep. For Sampang there are 15.61 people, Pamekasan is 1129, Sumenep 829 TKI). The majority of Indonesian migrant workers consist of women which is around $76 \%$.. Women migrant workers often experience several problems faced by migrant workers, including culture, language and communication, the performance of migrant workers, violence, rape, unilateral termination of contracts, standardized salary, overstaying, being pregnant and having children and lesbian issues. This happened because the average quality (input) of migrant workers from Madura was very low. Lack of knowledge, education and skills makes them experience violence in the destination country. The level of education of migrant workers is also inadequate, because most come from elementary and junior high school graduates. As a result, many of them worked in the informal sector, namely 89 percent working as domestic workers, 
5.6 percent as caretakers, 2.9 percent as production operators, 1.48 percent working in restaurants, while the rest spread as construction, cleaning, tailor, and other hired laborers [2].

\section{Method}

The research design was descriptive qualitative with data collection techniques interviewing in-depth observation and questionnaire dissemination. The research location was in Madura. This population was the highest sending migrant worker Sub-district in Madura, TKI, prospective TKI, with purposive sampling selection technique.

The object of this research is:

a) Indonesian Workers, prospective Indonesian Workers,

b) most TKI sending villagers in Madura,

c) Related agencies / authorities.

\section{Result}

\subsection{Motif, Destination Country, Indonesian Workers Welfare}

There are various motives behind the informants being migrant workers. Some of these motives are due to unemployment in the area of origin. They work only as farmers.

'What work before becoming a TKI? Yes, farmer, if there is no other work except farming here. (interview with Asna)

'What work before becoming a TKI? Farmer if here, there is no work other than farming (interview with Siti)

'What work before becoming a TKI? Well, it's normal if here the farm work doesn't have any other work besides the farmer except going to become a TKI ' [3].

Another informant said that the factor driving him to become a migrant worker was to pay off debts, the economy was in trouble. Another informant said that because of earning a living because of earning a living because of divorce with her husband.

'What factors encourage you to become a migrant worker? I did not have a husband, I was forced to leave to support my family and the needs of my two children. (interview with [4])

'What factors encourage you to become a migrant worker? I'm not sure my husband was forced to leave to support his family and my two children 'needs. (interview with Siti)

'What factors encourage you to become a migrant worker? After I divorced from my husband for 6 months, (interview with [3]) 
'What factors encourage you to become a migrant worker? Because the economy demands a lot of debt '... (interview with [5])

Another factor that became the motives of TKI departed in relation to prestige, namely wanting to go on the pilgrimage and building a new house. This can be seen from the interview quote with the informant below

'What factors encourage you to become a migrant worker? Yes, because I want to have a decent house to live in, like the other TKI houses, interview with [4])

What factors encourage you to become a migrant worker? Yes, because I want to have a decent house to live in, just like the other TKI houses, and also because I don't have it, my husband was forced to leave to provide for his family and the needs of my two children. (interview with Siti)

'What factors encourage you to become a migrant worker? I want to go on a pilgrimage and all work and the accuracy of someone who wants to depart for free I immediately made the decision to go to Saudi Arabia to become a TKI '(interview with [3]). YangWhat factors encourage you to become a migrant worker? want to carry out the Hajj. (interview with [5]).

\subsection{Destination and Employment of Indonesian Migrant Workers}

The country that is the destination of Indonesian migrant workers is Malaysia and Saudi Arabia. The reasons vary. TKIs who choose Saudi Arabia as a destination state say they want to go on a hajj and work at the same time. Some choose Malaysia because it is close and the costs are not expensive. The following is an excerpt from the interview with the informant:

'Why did you choose that country? Yes it is good if in Saudi Arabia because of the intention of virtue I want to do the Hajj and also while looking for money to repair my house and provide for my family. ' (interview with [3])

'Are you a migrant worker Which country and how many years have you become a TKI? I became a Saudi Arabian migrant worker for a contract for 2 years, after the contract I went straight home, but I was lured to be hajj again and told not to go home. ' (interview with [3])

'Are you a migrant worker Which country and how many years have you become a TKI? I have been in Saudi Arabia for 10 years as a TKI there. (interview with [3])

The work carried out by migrant workers is diverse. Female labor migrants usually work as housewives. Whereas male migrant workers work as builders, servants, restaurants. The salary received by migrant workers ranges from 600 to 1400 rials. The following is an excerpt from interviews with the participants

'As long as you become a migrant worker, what work do you have there? I am there at home work, so I do all the housework including childcare. ' (interview with [5]) 
'As long as you become a migrant worker, what work do you have there? I have been working as a house cleaner, cook and all household chores, including being a migrant worker, including child care. (interview with [3])

'How much income per month is the TKI of that country? 800 rials but if Indonesian money is around 2,000,000'. (interview with [5])

'How much income per month is the TKI of that country? The initial 800 rials were just working, but when it rose to 1,400 rials, the Indonesian money was around 2,000,000. (interview with [3]).

\subsection{Violence Experienced by Migrant Workers in Destination Countries}

Indonesian workers in the destination country do not always have good and pleasant stories. Many of the migrant workers experience unpleasant treatment. Some of these treatments included late salary, unpaid salary, torture, raids until repatriation. The following is an excerpt from the interview with the informant.

'Are you a migrant worker Which country and how many years have you become a TKI? I became a Saudi Arabian migrant worker for 7 years and was forced to go home because the police were together because the friend had a problem. (interview with [3])

What obstacles do you experience when becoming a migrant worker abroad? After from Saudi Arabia I was a Malaysian migrant worker but I asked to go home to my employer because I was not paid for 4 months and 25 days. (interview with [4])

'Alhamdulillah, I am safe so that the TKI there, the employer is good, but I am also sad that there are issues of torture against TKI, especially women. (interview with [3])

There are informants who have good experience. He gets a good employer, never presses, does not hit, only his employer always follows the informant wherever he is. Here is an excerpt with the informant [4]

"What do you know about the experience of migrant workers abroad? Are there people who experience obstacles and problems? Some of them really have TKIs who are tortured there and that depends on their respective employers, but Alhamdulillah my employer either never presses or hits me . But yes, only one of my unpleasant ones was there, I was always followed where I went with my employer, I was afraid to run away, he said, because I worked, I was presented, the contract could not be moved. (interview with [4])

According to the informant's experience, some of his friends were persecuted.

In addition to obstacles in the form of torture, beatings, late salaries, there are migrant workers who feel that the biggest obstacle is during education. Because if education does not pass, it will not be sent abroad. Here's the official quote:

Are there barriers experienced by migrant workers during the migration process? Alhamdulillah, there are no obstacles whatsoever. Only the school (education) is difficult, 
because it is wrong to say that it might not pass the school or education of migrant workers and it will not be departed. (interview with [4]

These migrant workers, when faced with problems relating to their employers, usually have their own strategies to get out of the problem. Some of these strategies include changing employers,

As long as you become a migrant worker, what work do you have there? During my time as a migrant worker, I worked as a maid and my job there was to wash away mopping as a baby sitter, etc. for all household chores, but I moved my employer while I was a migrant worker because when my employer was not suitable for me for a month, I immediately moved. (interview [3])

Are there barriers experienced by migrant workers during the migration process? I spent 4 years working there from the first employer because there was something I lacked with my first employer. (interview with [5]).

\section{Conclusion}

The availability of access to telephone services in the village has benefited the population, but more to social benefits. Transportation facilities that are very minimal make the presence of telephones a communication solution for the village community. Benefits of the availability and access to telephones in rural areas are providing easy communication for residents in the case of social affairs and work matters. The village community as a telephone user has no obstacles in using it for matters of social relations and employment relations. The availability of telephones provides convenience, fast, efficiency, and without limits of distance in delivering messages/information.

The presence of telephone in the village has not been maximized as a media that connects village sellers and buyers outside the Lebak area. This is in line with the opinion of Galloway that the presence of telephones in the Lebak region has not provided maximum economic benefits [6]. Small businesses in rural areas cannot reach modern customers effectively [7]. This obstacle occurs because of the limitations of telephone technology in opening up village market opportunities and/or limitations of telephone technology to bring buyers outside the Lebak area. Phone technology is only limited as a medium of communication between sellers in the village and known buyers. The extensive relationship between sellers and buyers does not occur only with the presence of telephones, because of the limitations of telephone performance as a communication tool that only connects to known people. In other words, the presence of a telephone cannot expand the village market network.

Extending the village market network or overcoming barriers to the relations of sellers and buyers outside the Lebak area needs to enroll non-human actors [8] or in other words need to adopt other media technology [9]. Overcoming these obstacles requires the presence of media technology, some of which are web-based applications and Short Message Service gateways [7]; [10]. The presence of this media technology can bring together sellers and buyers (see figure 2). 


\section{References}

[1] "Data from East Java Disnakertransduk." .

[2] D. . dkk Noeswantari, "Mencegah Traffiking Melalui Prosedur Penempatan dan Perlindungan Tenaga Kerja Indonesia." .

[3] S. Zahro, "woman migrant worker." .

[4] Sitti, "woman migrant worker.".

[5] Asna, "woman migrant worker.".

[6] L. Galloway, "Can broadband access rescue the rural economy?," J. Small Bus. Enterp. Dev., vol. 14, no. 4, pp. 641-653, 2007.

[7] W. Richmond, S. Rader, and C. Lanier, “The 'digital divide' for rural small businesses," J. Res. Mark. Entrep., vol. 19, no. 2, pp. 94-104, 2017.

[8] M. Callon, "Some Elements in a Scoicology of Translation: Domestication of the scallops and fishermen of St. Brieue Bay," in Power, Action, Belief: A new sociology of knowledge, L. John, Ed. London: Routledge and Kegan Paul, 1986, pp. 196-233.

[9] H. E. Hudson, "Digital Diversity: Broadband and Indigenous Populations in Alaska," J. Inf. Policy, vol. 1, pp. 378-393, 2011.

[10] A. Salim, "Management Information in Rural Area: A Case Study of Rancasalak Village in Garut, Indonesia," Procedia Technol., vol. 11, pp. 243-249, 2013. 